HUYNH THI TRUC Giang

$\mathrm{PhD}$ student

PTE ÁJK

lecturer

Can Tho University Vietnam
DOI: 10.15170/DIKE.2021.05.01.07

\title{
Beginning of Protection of Children's Rights in the Vietnamese Legal Development
}

\begin{abstract}
In Vietnam, the government has focused on protecting children's rights for many years, especially after the State signed the United Nations Convention on the Rights of the Child; however, whether such rights existed during the French colonial rule in Vietnam is an issue that needs to be clarified. This paper is formulated on the premise that the protection of children's right was legislated in the Vietnamese law during the French occupation. In order to prove this position, this paper considers the laws enforced during the French colonial rule in Vietnam (1858-1945).
\end{abstract}

Keywords: children's rights protection, Vietnamese law, French colonial rules

\section{Introduction}

Children are subjects with incomplete physical and intellectual development, so they are vulnerable to abuse. Initially, child abuse only covered acts that harm the body or honour and dignity of the child. Gradually, along with the development of society, the form, level of abuse and acts of abuse against children are becoming more sophisticated, dangerous and varied. In this regard, international and national laws must have provisions dealing with acts of child abuse and define stakeholders' rights and obligations in the protection of children and children's rights. Up to now, Vietnamese law has quite fully and in detail tackled children's rights and the protection of these rights.

In order for the authorities enforce such rights effectively, there has been many studies on the current Vietnamese law concerning the implementation of children's rights. However, it is necessary to begin the research on the protection of children's rights from the early stages of the Vietnamese legal history. This approach would lead to a more comprehensive research on Vietnamese children rights protection laws and also identifies their strengths and weaknesses. Then, from the results we can draw the necessary lessons to be applied for a more effective implementation of children's rights protection laws in Vietnam. This article analyses the protection of children's rights in Vietnam's law during the French occupation with a view to determining the origin of the protection of children's rights, the basis and the extent of the protection of these 
rights in the Vietnamese law. The article has used an integrated method of study analysis and comparative methodology to conduct research.

\section{The right of the child in the current Vietnamese law}

Although researching on the protection of children's rights in the current Vietnamese law is not the primary aim of this article, it serves as a basis for analysing and evaluating the status of children's rights during the French colonial rule in Vietnam.

Children's rights were first recognized in the 1924 Geneva Declaration. ${ }^{1}$ By 1989, the United Nations Convention on the Rights of the Child $^{2}$ made a prominent mark in international law when it officially identified children's rights. The Convention recognizes that children have four groups of rights: the right to survival, the right to protection, the right to development and the right to participate. Also, it requires member states to ensure all the best possible conditions to protect children's rights in their countries. ${ }^{3}$

Vietnam was the first country in Asia and the second country in the world to ratify the United Nations Convention on the Rights of the Child in 19904. Since that time, Vietnam has reviewed the legal system, supplemented, and issued new documents to facilitate the implementation of the protection of children's rights in the country. In Vietnam, children's rights are considered as human rights applied exclusively to the child. Such rights ensure that a child is not an object in their development, but a subject who has rights and obligations.

In order to protect children's rights, the law must adopt a two-pronged approach. Firstly, to prevent acts that infringe on children's rights. Second, dealing with infringements of rights.

Specifically, concerning the child protection, the 2013 Vietnamese Constitution ${ }^{5}$ clearly and firmly states in Clause 1, Article 37 as follows: 'Children shall be protected, cared for and educated by the State, family and society; children may participate in child-related issues. Harassing, persecuting, maltreating, abandoning or abusing children, exploiting child labour or other acts that violate children's rights are probibited'. Thus, 'the 2013 Vietnamese Constitution is the premise and legal foundation for substantial and breakthrough improvements in childcare and protection' 6

Next is the detailed implementation of some rights of children in the family and the respective obligations of family members as stipulated by Vietnamese Marriage and Family Law. ${ }^{7}$ These are, Obligations and rights of parents (Article 69), Obligation and right to care for and raise

\footnotetext{
${ }^{1}$ The Geneva Declaration of the Rights of the Child 1924 was adopted by the League of the Nations in 1924, and adopted in an extended form by the United Nation in 1959. See https://www.humanium.org/en/text-2/.

2 The United Nations Convention on the Rights of the Child was adopted by the UN General Assembly and opened it for signature on 20 November 1989. See https://ihl-databases.icrc.org/applic/ihl/ihl.nsf/INTRO/540.

3 Unicef, https://www.unicef.org/vietnam/vi/c $\% \mathrm{C} 3 \% \mathrm{~B} 4 \mathrm{ng}-\mathrm{0} \% \mathrm{C} 6 \% \mathrm{~B} 0 \% \mathrm{E} 1 \% \mathrm{BB} \% 9 \mathrm{Bc}-\mathrm{li} \% \mathrm{C} 3 \% \mathrm{AAn}$ h $\%$ E1 $\%$ BB $\%$ A3p-qu $\%$ E1 $\%$ BB $\% 91$ c-v $\%$ E1\%BB $\% 81$-quy $\%$ E1 $\%$ BB $\% 81$-tr $\%$ E1 $\%$ BA $\%$ BB-em.

4 DiNH THI, Bảo vệ quyền trẻ em trong pháp luật Việt Nam hiện hành 65.; Unicef, https://www.unicef.org/vietnam/vi/c\%C3\%B4ng- $\%$ C6 $\%$ B0\%E1\%BB $\%$ BBc-li $\% \mathrm{C} 3 \% \mathrm{AAn}-\mathrm{h} \% \mathrm{E} 1 \% \mathrm{BB} \% \mathrm{~A} 3 \mathrm{p}-$ qu $\%$ E1 $\%$ BB $\% 91$ c-v $\%$ E1\%BB $\% 81$-quy $\%$ E1\%BB $\% 81$ n-tr $\%$ E1\%BA $\%$ BB-em.

5 Vietnamese Constituion was issued by Vietnamese National Assembly on 28 November 2013, https://thuvienphapluat.vn/van-ban/Bo-may-hanh-chinh/Hien-phap-nam-2013-215627.aspx.

${ }^{6}$ See NGuYÊn THI, Quyền trẻ em trong pháp luật Việt Nam hiện nay, passim.

${ }^{7}$ Law on Marriage and Family number 52/2014/QH13 was issued by the 13 Vietnamese National Assembly on 26 June 2014, https://thuvienphapluat.vn/van-ban/Quyen-dan-su/Luat-Hon-nhan-va-gia-dinh-2014-238640.aspx.
} 
(Article 71), Obligation and right to educate children (Article 72) and, Children's right to have their own property (Article 75). These rules are the basis for parents to determine what they must do to protect their children's rights. In other words, Vietnam's Law on Marriage and Family states that, loving, caring for, educating and protecting children is not only a right but also an obligation of parents because 'affection and safety are essential factors for the physical, mental, emotional and intellectual development of any child. ${ }^{8}$

The Children's Act is the most detailed and complete document specifying the specific children's rights protected by the State as well as the mechanisms for these rights to be implemented and effectively secured. The Vietnamese Children's Act $2016^{9}$ stipulated that children have twenty-five rights that are drawn from The United Nations Convention on the Rights of the Child (1989); however, the legislators also adjusted them to suit Vietnam. These rights are divided into four groups: in the first are the rights ensuring children's right to life. These are: Right to life (Article 12), Right to be cared for and nurtured (Article 15), Right to live with their parent(s) (Article 23), Right to receive surrogate care and to be adopted (Article 24), Right to birth registration and nationality (Article 13); the second group ensures the children's development. They include, Right to health care (Article 14), Right to education, study and development of talent (Article 16), Right to engage in play and recreational activities (Article 17), Right to preserve and promote character (Article 18), Right to freedom of belief and religion (Article 19), Right to assets (Article 20), Right to privacy (Article 21); the third group comprises rights ensuring the right of a child to be protected such as the Right to be protected from sexual abuse (Article 25), Right to be protected from labour exploitation (Article 26), Right to be protected against violence, neglect or abandonment (Article 27), Right to be protected from trafficking, kidnapping, swap and appropriation (Article 28), Right to protection from narcotic substances (Article 29), Right to be protected in the course of proceedings and taking of actions against administrative violations (Article 30), Right to be protected while suffering from natural disasters and calamities, environmental pollution or armed conflict (Article 31), Rights of children with disabilities (Article 35); and the last one, ensuring the right to be participated in such as Right to social security (Article 32), Right to access to information and social activities (Article 33), Right to state opinions and attend meetings (Article 34), Rights to stateless children and refugee children (Article 36). Although the Children's Law 2016 stipulates numerous legal rights for children, it is not an abstract collection of these rights, because these provisions distinctly define the obligations of concerned subjects when protecting children's rights.

The protection of children's rights will encounter challenges if the Vietnamese legal system does not prescribe measures to deal with those who commit acts infringing upon children's rights. Therefore, the 2015 Act on Criminal Law ${ }^{10}$ has done this with a number of laws, for example Murder (Article 123), Murder or abandonment of a newborn child (Article 124). These crimes are recorded to handle and discourage those who violate the right to life of children. Murder is an unlawful act committed by a person with criminal capacity depriving another person of the right

\footnotetext{
8 BILTON, Nhập môn Xã hội học 30.

${ }^{9}$ Children Law number 102/2016/QH13 was issued by the 13 Vietnamese National Assembly on 05 April 2016. See https://thuvienphapluat.vn/van-ban/Giao-duc/Luat-tre-em-2016-303313.aspx.

${ }^{10}$ Criminal Law number 100/2015/QH13 was issued by the 13 Vietnamese National Assembly on 27 November 2015. See https://thuvienphapluat.vn/van-ban/Trach-nhiem-hinh-su/Bo-luat-hinh-su-2015-296661.aspx.
} 
to life. 'The subject of murder is the living buman body. ${ }^{11}$ Thus, while being attacked, people will resist by attacking others due to their survival instincts. However, if the person being attacked is just a child whose physical development is not yet complete, the ability to defend himself is minimal. Therefore, to protect children's rights, Vietnam's Criminal Law stipulates the penalty of 12 to 20 years in prison, life or death sentence as compared to just 7 to 15 years in prison in other cases.

Along with the violation of children's right to survival, 'the murder of a newborn still seriously violates the Convention on the child's rights to which Vietnam is a signatory and social morality, that is motherhood. ${ }^{12}$ Rape of a person under 16 (Article 142), Engaging in sexual intercourse or other sexual activities with a person aged from 13 to under 16 (Article 145), Molestation of a person under 16 (Article 146), employment of a person under 16 for pornographic purposes (Article 147), trafficking of a person under 16 (Article 151), swapping a person under 1 year of age (Article 152), Abduction of a person under 16 (Article 153)are crimes and sanctions that Vietnam Criminal Law applies to those who infringe upon children's rights to protection.

Clause 1, Article 142 of the Vietnamese Penal Code states that 'A person who commits any of the following acts shall face a penalty of $07-15$ years' imprisonment: a) Use of violence or threatens to use violence or takes advantage of the victim's defencelessness or otherwise engages in non-consensual sexual intercourse or other sexual activities with a person aged 13 to under 16. b) Engaging in sexual intercourse or other sexual activities with a person under 13 years. 'Thus, to protect children's rights, the State of Vietnam stipulates that Rape's penalty depends on the victim's age and consensus for the offender's behaviour.

Criminal acts specified in Article 145 of the Vietnam Penal Code are acts of an adult having sexual intercourse in the form of sexual intercourse or performing other sexual relations with a person aged from full 13 years to under 16 years. Despite the consent of children, they still have limited awareness and life experience at this age, making decisions about sexual intercourse improperly, easily emotional, and being drugged' ${ }^{13}$ Therefore, to protect children's benefit, the Vietnamese criminal law has defined this as an offence.

In addition, to protect children from acts of sexual abuse, Article 146 of the Penal Code of Vietnam also provides for cases of Molestation of a person under 16. Accordingly, any person who molests a person under 16 for purposes other than sexual intercourse or other sexual activities shall face a penalty of 6-36 months imprisonment.

'Molestation acts are understood as acts aimed at satisfying the offenders' sexually in any form but not have sexual intercourse with the victim. For example, the act of touching, undressing, massaging the victim's body, and so on to sexual gratification. ${ }^{14}$

Employment of a person under 16 for pornographic purposes is also considered an offence under Article 147 of the Vietnam Criminal Law.

\footnotetext{
11 Tran Van - Phung The - Le VAn - NguyÊn Mai - Pham Than - NguyÊn Ngoc - Pham Thi, Bình luận Khoa học Bộ Luật hình sự năm 2015 - Phần các tội phạm 38.

12 Tran Van - Phung The - Le VAN - NguYÊn MaI - Pham Than - NguyÊn Ngoc - Pham Thi, Bình luận Khoa học Bộ Luật hình sự năm 2015 - Phần các tội phạm 39.

13 Tran VAn - Phung The - Le VAN - NguyÊnN MAI - Pham Than - NguYÊn Ngoc - Pham Thi, Bình luận Khoa học Bộ Luật hình sự năm 2015 - Phần các tội phạm 89.

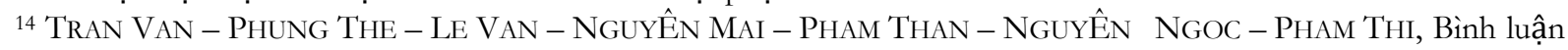
Khoa học Bộ Luật hình sự năm 2015 - Phần các tội phạm 38.
} 
Precisely, offenders have been manipulating, seducing, or forcing people under 16 years of age to perform pornography. Pornographic performance is the act of a person or group of people performing dance acts or other forms of performance for others to see aimed at sexual arousal. ${ }^{15}$

\section{Vietnamese law during French colonial rule (1858-1954)}

'On September 1, 1858, Admiral Rigault de Genouilly brought 14 warships and 3,000 troops to attack Da Nang ${ }^{16}$ province and then extended the conquest to Southern Vietnam provinces. ${ }^{17}$ 'Under the increasing pressure of French colonialism, the Nguyen Dynasty, which governed the territory of Vietnam from 1802 until 1946, accepted the signing of the Treaty of Saigon in 1962. Accordingly, the South of Vietnam became a territory of France and set under full control of the French government ${ }^{18}{ }^{18}$ The feudal government of the Nguyen Dynasty only ruled the North and Central regions afterwards. In 1883, France increased the expansion of invasion to the North and Central of Vietnam. Due to the weakness of the Nguyen Dynasty, France forced King Nguyen to hand over the North and the Centre to France for protection. The protection meant that the North and Central regions were not only subject to the management of the Nguyen Dynasty but also under the control of the French colonialists. ${ }^{19}$

Since the rulers differed in each region, the legal system in each locality is not the same. In other words, each region was assigned a distinct political status and, by extension, its own civil code. 20 'In the South, because it was a French colony, the legislative power at that time belonged to the French. ${ }^{21}$ On October 3, 1883, the President of France promulgated the Civil Code to apply in South Vietnam. In terms of form, from its layout to the articles, this law is identical to the first book of the French Civil Code of 1804. In terms of content, this is a law with precise personal nature, different from the spirit of the traditional legal spirit of Vietnam, respect for the family. ${ }^{22}$ Meanwhile, the North and the Centre, were both managed by France and the Nguyen Dynasty. At first, France still applied the law promulgated by the Nguyen Dynasty-Gia Long Code to ensure the people's stability and consensus.

Gia Long Code is one of the two most prominent laws of the Vietnamese feudal regime. If Vietnam had the Hong Duc Code in the Le dynasty, which was enacted in the 15th century, the Gia Long law in the cursed period was considered a complete version of the old Vietnamese law. ${ }^{23}$ This code was applied in the Northern provinces until 1931, then France promulgated the Northern Civil Code. The text is written in French and Vietnamese. In Article 2 of the Decree

\footnotetext{
15 Tran Van - Phung The - Le VAN - NguyẾn Mai - Pham Than - NguyÊn Ngoc - Pham Thi, Bình luận Khoa học Bộ Luật hình sự năm 2015 - Phần các tội phạm 93.

${ }^{16} \mathrm{Da}$ Nang is the central and largest city in Central Vietnam.

${ }^{17}$ NGuYÊn DiNH, Chế độ thực dân Pháp trên đất Nam Kỳ (1589-1954) 21-25.

18 See NguYÊn THi My, The Impact Of The French Colonial Law On the Development of Matrimonial Property Law in Vietnam.

${ }^{19}$ See NguYÊn Thi My, The Impact Of The French Colonial Law On the Development of Matrimonial Property Law in Vietnam.

${ }^{20}$ NGUYÊN THI MY, The Matrimonial property Law in Vietnam 1858-1975 in the Mirror of the European Legal Development 309-316.

${ }^{21}$ VU VAN, Dân Luật Khái luận 281.

22 VU VAN, Dân Luật Khái luận 283.

${ }^{23}$ NGUYÊN QUANG, Bước đầu tìm hiểu Luật Gia Long 7.
} 
promulgating the Northern Civil Code dated March 30, 1931, the existing civil laws in the North, that are contrary to this Civil Code are annulled, significantly the articles in Gia Long Code. ${ }^{24}$

In the Centre, Gia Long's code was complied with until 1936, when France promulgated the Intermediate-Central Civil Law that was also issued in French and Vietnamese. ${ }^{25}$

The Northern Civil Code has 1455 article sections, which were divided into a preliminary section and four volumes. The first provides for the family, the second book imposes property, the third book defines obligations and contracts, and the fourth stipulates on evidence. The first book is more distinctive than the rest, because, in this book, it is clear that the legislators made efforts to retain our traditional customs, especially in matters of family organization and inheritance. However, on many issues, such as parent-child relations and the protection of the person who is unable to defend themselves is not defined in our traditional laws. Therefore, its usage must be applied in accordance with European law. ${ }^{26}$

The Northern Civil Code of 1931 was used as a template by legislators in the Central region to compose the Central Civil Code, which recorded nearly all the Northern law terms, except for a few minor changes.

The Central Civil Code has 1709 articles. It has more 245 articles than the Northern Civil Code because the contracting issues in this document were applied according to the French Civil Code, which defines in detail numerous issues about this.

In summary, Vietnamese law during the French colonial period includes documents promulgated by the French and those promulgated by the Vietnamese state and also used by the French. These documents include The Gia Long Code, the Southern Civil Code, the Central Civil Code, and the Northern Civil Code.

\section{Protection of the rights of children in the provisions of the Vietnamese Law during the French conquest period}

When analysing the French colonial regulations in Vietnam on protection of children's rights by comparing them with the current Vietnamese laws, it is easy to find that children's rights as regulated in the documents are unclear and incomplete.

The most noticeable point is the affirmation that the State, family, and society protected children's rights. If this content is recorded in the current Vietnamese Constitution-the most valuable legal document in Vietnam, it was absent in the French colonial rules.

There are two reasons for this state of affairs. The first is due to the nature of Vietnamese laws during the French invasion. The laws were crafted to serve mainly the interests of the ruling class at that time - the French colonial masters. Besides, Vietnam had a past of being under Chinese domination for thousands of years. As a result, Chinese Confucianism's patriarchal ideology still left a massive mark in Vietnamese law. Therefore, the role of the child in society is not respected.

\footnotetext{
${ }^{24}$ VU VAN, Cổ Luật Việt Nam và Tư Pháp Sử Quyển 1-Tập 1215.

${ }^{25}$ Vu VAN, Cổ Luật Việt Nam và Tư Pháp Sử Quyển 1-Tập 1215.

${ }^{26}$ VU VAN, Dân Luật Khái luận 290.
} 


\subsection{Right to survive}

The right to survival is an inherent natural right of children. This right is one of the rights recognized first in the United Nations Convention.

Regarding the importance of this right, Blackstone in the $17^{\text {th }}$ century described life as, 'an immediate gift from God, a right inherent by nature in every individual.' Blackstone further observed that 'the right to life is of such high value that it can even supersede murder if committed in self-defense.'27

As a member of the Convention, Vietnam has also provided this right in the first Article of the Chapter on children's rights in the current law. All of this shows that national legislators have recognized children's right to life as of considerable importance. However, this right is not explicitly specified in the Vietnamese laws applied under the French colonial rule: the Southern Civil Law, the Civil Law of the North, and the Central Civil Law. Only in the Gia Long Code, do we have provisions on the crime of high treason acts recorded. Children under 15 years of age are excluded from the death penalty if they are related to the people who have conspired to commit treason. ${ }^{28}$ Under the provisions of Gia Long Code, those who have been found guilty of high treason, their relatives will be executed (Article 223). However, this article also stipulates that if the offender's children are under 15 years of age, they will only be enslaved. From the arguments above it can be concluded that the right of children to life was protected during the Nguyen Dynasty.

The reason for protecting children's right to life here stems from the argument that children under 15 years old are incapable of making sound judgements. Even though they may be living with their parents, whether their parents' behaviour is right or violates the law, children cannot recognize right from wrong. Therefore, the legislators waived the death penalty for them.

\subsection{Right to birth registration}

In many countries, including Vietnam, the child's right to birth registration is a fundamental right, an essential premise for children to exercise their next rights, namely the right to nationality and the right to education/study; the right to health care and, the right to assets. This means that, if the child does not have a birth certificate, they will not be able to exercise the remaining rights, or it will take a lot of money, time and effort to do it. However, the absence of a birth certificate often occurs among children who were born into impoverished families in society and whose daily concern is simply food. Therefore, when it comes to complicated legal requirements they are not concerned for they have more pressing daily survival needs. Vy's case in $\mathrm{Ho}_{0} \mathrm{Chi}$ Minh City, Vietnam is an example. Because she did not have a birth certificate, she was not entitled to free treatment at the hospital after a traffic accident. ${ }^{29}$

The legislators realized the importance of birth registration and birth certificate. Since the French colonial period, Vietnamese law has recognized these rights in all three civil laws in the Southern, the Northern, and the Central. Accordingly, the Southern Civil Code stipulated that the

\footnotetext{
${ }^{27}$ Blackstone, Blackstone's Commentaries on the Laws of England 101. See also MCCLOSEKEY, The death penalty and the right to life 1545.

${ }^{28}$ NGUYỀn QuANG, Bước đầu tìm hiểu Luật Gia Long 32.

${ }^{29} \mathrm{NHU}$, Cứu tinh của trẻ sơ sinh không có giấy khai sinh.
} 
time limit for birth registration for a child was eight days after the child's birth. The Southern birth procedure was similar to the Northern and Central civil code whereby the registration of birth must include a newborn's presence. If the newborn could not come due to illness, the civil status official would come to the home to verify the birth.

The deadline for birth registration for children defined in the North Civil Code and Central Civil Code was one month. ${ }^{30}$ If the birth registration was not done on time, a fine would be imposed. It is the regulation stipulated in Article 21 of the Northern Civil Law and the Central Civil Code. In addition, Article 25 of these two documents required that every child be registered at birth regardless of whether the mother survived the birth or not. In the event that the mother died during childbirth and the father was present, he would handle the registration process. If the father was not present, the same would be done by a relative. Even the law envisages that, in some cases, the registration would be done by a neighbour or the person who witnessed the childbirth. This provision has created conditions for all children to be registered for birth in the North and Central Vietnam.

Moreover, the issuance of birth certificates to children right after completing the birth registration procedure has created favourable conditions for children to enjoy the remaining rights as citizens of Vietnam. This is one of the advantages of Vietnamese law, compared to some countries, even developed countries like Australia. ${ }^{31}$ The child's right to birth registration and the issuance of a child's birth certificate are not the same. As a result, a child may be registered for birth and yet not be given a birth certificate to exercise other rights. This comparison can help us conclude that, although the right to birth registration for a child was merely recorded in the legal documents of Vietnam during the French colonial period, currently, it has been partially implemented to protect children's rights.

During the French colonial rule, the birth certificate was also used as evidence to prove the mother and child relationship. The relationship between father and child will be proven based on the mother's marriage certificate. ${ }^{32}$ This means that the husband of the woman who gives birth will be the child's father that the woman gave birth to. Since it is only speculative, the paternity under the Northern Civil Law, Central Civil Law and Southern Civil Law can be denied by the father suing in court. However, this waiver will not be accepted if the husband attended the birth certificate's testimony, signed the deed, or clearly states that the husband did not know sign. ${ }^{33}$ Thus, the birth registration for a child is essential, particularly if the child's birth registration happens in the presence of the father.

\subsection{Right to nationality}

Nationality is the legal status that defines the relationship between an individual and a particular State. The nationals are subject to the State's absolute jurisdiction and enjoy legal capacity with the protection of the State. Therefore, children, as individuals, will have the right to nationality. ${ }^{34}$ In other words, a child's right to

\footnotetext{
30 VU VAN, Việt Nam Dân Luật Lược Khảo 189.

${ }^{31}$ GERBER - GARGETTT - CASTAN, Does the right to birth registration include a right to a birth certificate 434.

32 Vu VAN, Việt Nam Dân Luật Lược Khảo 189.

33 VU VAN, Việt Nam Dân Luật Lược Khảo 193.

${ }^{34}$ DINH THI, Bảo vệ quyền trẻ em trong pháp luật Việt Nam hiện hành 5.
} 
nationality creates the legal status for a child to be officially recognized as a citizen of a country. As such, children will enjoy all the rights and have to fulfil citizenship obligations (if any) following the Constitution and the law. Besides, children will also receive protection from the State if international legal problems arise.

During the French colonial period, in the South, the 1883 Civil Code was rather sketchy, so there was no record of a child's citizenship. Article 13 of the Central Civil Code and the North Civil Code provide for the rights of children to have Vietnamese nationality. Accordingly, the determination of the child's nationality will be done according to two principles. First, the nationality of a child is determined by the nationality of the parent. Second, the child's nationality is determined based on the territory where the child was born.

\subsection{Right to know their origin}

Nowadays, in the legal aspect the right to know one's origin is understood in a relatively broad sense. It is the right to know one's parentage, i.e. one's biological family, antecedents and one's condition of birth. ${ }^{35}$

In Vietnam, even in the current state, there is not yet a unified and complete concept of the contents of this right. Therefore, the author will analyse this right based on the provisions of Article 7 of the United Nations Convention and Article 23 of the current Children's Act in Vietnam. Accordingly, the children's right to know about their origin in this article is the right to know about their parents.

During the French invasion, the Vietnamese constitution provided for the right of children to know their parents. During that period children had a right to know their parents even if they were born out of wedlock. However, it is necessary to establish the difference in the enforcement of this right in the current period and during the French colonial period in Vietnam. Specifically, since joining the 1989 United Nations Convention on the Rights of the Child and the enactment of domestic laws that recognize the child's right to know their parents, this right is enforced with the primary goal of protecting the child, as an equal subject with other adult subjects. On the contrary, during the French colonial period, as analysed above, due to the paternalist's roots, ${ }^{36}$ the permission for children to identify their origins is mainly to protect their parents' interests. The interests of the children in these situations, if any, are secondary. 'Although patriarchal ideology has appeared for a long time, its negative influence on the Vietnamese people's spiritual life was still very evident during the French invasion. ${ }^{37}$

During the French colonial rule, the right to know one's biological parents was exercised by either the children themselves or their parent/s. The first is the recognition a child gets from their parents. Parents can recognize their children at the time they register their baby's birth or after birth registration. Article 163 of the Northern Civil Code and Article 162 of the Central Civil Law stipulates that when a father registers a birth out of wedlock and recognizes that child as his own, the birth certificate will be considered evidence of child adoption. The Civil Code in South Vietnam

\footnotetext{
35 PRELOZNJAK, Modern challenges in the implementation of the child's right to know his origin 1175.

${ }^{36}$ Patriarchal ideology has appeared in Vietnam since feudal times due to the influence from China.

${ }^{37}$ HoANG THU, Ảnh hưởng của quan niệm đạo đức Nho giáo đến đời sống đạo đức ở Việt Nam hiện nay 13.
} 
also has a similar regulation. According to a Case on May 25, 1930 in Saigon Court, when parents brought their child to the administrative officer and granting the child use their surname is considered that the recognition is validated ${ }^{38}$. Vu Van Mau supposed that 'this was a reasonable and bumane regulation. If the recognition of the child was required with strict formal conditions, the father of the child could not done it because he does not understand the law. Therefore, it could damage the interests of the illegitimate child..$^{39}$

Child recognition can still be done after the birth registration is completed. In Southern Civil Law, after the child's birth has been registered, the parent has just recognized the child, and in order to complete the process, the child recognition must also be done in court. After the court process, the parents would then pass such a case to the civil status official to note their birth certificate's recognition. However, the time limit for recognising a child in court is not regulated in the Southern Civil Code. ${ }^{40}$ Article 165 of the Northern Civil Law and Central Civil Code in Article 163 states that even though the birth registration is finished, the civil status official has the competence to recognize a child at the request of the parent's child. This deed must be recorded in the civil status register in the presence of two witnesses.

Secondly, the right to know parents is exercised by children. Article 74 of the Northern Civil Code prohibits parents' admission by the child because children cannot directly sue their parents. 'This provision is intended to avoid damaging filial piety in the Vietnamese family, but the solution is too strict for those born out of wedlock., 41

In the Southern Civil law, if the father recognized an illegitimate child, then the child only needed to prove that they were born by the woman they claim to be the mother. If the father did not recognize the child, the child must sue for recognition within two stages. The first step is, proving they were born by the woman in question, and they and the child the woman gave birth to are the same person. ${ }^{42}$ Article 176 of the Central Civil Code stipulates that when the child born out of wedlock is a minor and whose mother has not sued to determine their father, that child can also sue when he is a mature so that the court recognizes who his father is. The deadline is only one year after they attain maturity.

After the recognition of a child is completed, Article 184 of the Northern Civil Code and Article 182 of the Central Civil Law stipulates that: children will have the obligations and rights to their parents as if they were born in wedlock. The Southern Civil Code does not provide for the status of an illegitimate child who has been recognized by their parents. However, we cannot use theoretical methods to conclude that an illegitimate child will have the same rights as a child in wedlock after being recognized by their parent because, in chapter VII of the Southern Civil Code, illegitimate children have only all their rights in wedlock when their parents are married. ${ }^{43}$

\footnotetext{
38 VU VAN, Việt Nam Dân Luật Lược Khảo 222.

${ }^{39}$ VU VAN, Việt Nam Dân Luật Lược Khảo 223.

${ }^{40}$ VU VAN, Việt Nam Dân Luật Lược Khảo 227.

${ }^{41}$ VU VAN, Việt Nam Dân Luật Lược Khảo 259.

${ }^{42}$ VU VAN, Việt Nam Dân Luật Lược Khảo 241.

${ }^{43}$ VU VAN, Việt Nam Dân Luật Lược Khảo 267.
} 


\subsection{Right to education}

Educational activities in general and education for children in Vietnam have existed since feudal times. During the French colonial period, Vietnamese education was organized and operated based on Western enlightenment and freedom ideology, with a vocational education philosophy, different from the existing Confucian ideology and thousands of years old history. As a result, our country's education has had a profound change. One of the new features is that women can go to school and participate in teaching and other social work. It can be said, from a cultural perspective, this is an educational value of this period'- ${ }^{44}$

In the Northern Civil Code and the Central Civil Code, when they stipulated about the rights of the patriarch, it also defined that, children could study at home or go to school depending on the economic condition of their parents (Article 218 of the Northern Civil Code and Article 214 of the Central Civil Code).

In the South, in the 1883 Civil Code, there is absolutely no record about the children's right to education. However, through policies and decrees issued in the Southern Civil Code, it has been shown that children in this region can still be educated in one or two ways. First, study at home and study at schools built by French colonial masters.

The French colonialists focused on developing education for the fundamental reasons such as: it is necessary to conquer the spirit of the indigenous people after completing the land conquest; need to train a loyal maid class; it is necessary to create conditions for the French to communicate with the Vietnamese people without going through intermediaries directly. These reasons govern the content of a new education, which is gradually formed and developed in colonial times. ${ }^{45}$

According to Nguyen Dinh Tu's research, ${ }^{46}$ after the French conquered the South, to protest against the French colonialism, the teachers did not go to work, or went to Hue city ${ }^{47}$ and the students quit school to join the army. Faced with this situation, the French colonialists opened schools, granted scholarships, provided all accommodation facilities, clothes, pants and books to students. Moreover, the colonialists also allowed the use of Chinese characters in education. The French colonialists did all this with the primary purpose of winning the hearts of the people and have students return to school.

After that, on November 17, 1874, the Governor of the Southern Provinces, Krant, issued Decision No. 282 with 4 chapters and 23 articles that laid the first foundation for public education in Cocbinchina under the new regime. Accordingly, in addition to teaching Chinese characters in primary school, the students had to learn more Vietnamese characters and French. In the program from secondary school upwards, they were not taught about Vietnamese geography, but they were taught about French geography and the French colonies.

It can be seen that, 'different from traditional education, the education set up by the French in Vietnam in this period was quite comprehensive. The contents of social sciences, natural sciences, ethics training, and health are included in all educational levels. ${ }^{48}$

\footnotetext{
44 NGUYÊN HOA, Trường nữ sinh thời Pháp thuộc ở Việt Nam: Từ góc nhìn quyền văn hóa.

45 Tran THI THANH, Nho học và giáo dục công lập ở Nam Kỳ thuộc Pháp thời kì 1867-1917 20.

${ }^{46}$ NGuYÊn DinH, Chế độ thực dân Pháp trên đất Nam Kỳ, Tập 2287.

${ }^{47}$ The capital of Vietnam at that time. It was also the place ruled by the feudal government of the Nguyen Dynasty.

${ }^{48}$ NGUYÊN HoA, Trường nữ sinh thời Pháp thuộc ở Việt Nam: Từ góc nhìn quyền văn hóa.
} 
Although the implementation of French education policies is not to ensure the children's right to education, the school also contributes creating a generation of intellectuals, contributing to Vietnam's education development.

\subsection{Right to receive surrogate care and to be adopted}

In the three Civil Codes the right of a child to be adopted is one of the most clearly recognized Vietnamese law during the French invasion.

Under Article 185 of the Northern Civil Code and Article 183 of the Central Civil Code, the adoptive person must be a minor, regardless of whether one is a girl or a boy.

In Gia Long Law, adoption is also provided for in Article 76. Accordingly, a person can adopt a child whether they are related or not. After being adopted, if the child has a different surname from the adoptive father, Gia Long Code allows the child to keep its surname unless the adopted child is an abandoned child under three years old as prescribed in Clause 3 and Clause 5 Article 76 Law on Gia Long. ${ }^{49}$ Under the Southern Civil Law, only minors can be adopted. This means that they must not be more than 21 years old. The person adopted can also be a boy or a girl. The adopting person must be over 25 years old, and there is no regulation on the age gap between the recipient and the adoptive child in this code.

Although the model for stipulating the Southern Civil Law is derived from the French Civil Code, but 'compared to the French Civil Law, the Southern Civil Law is much more accommodating because the French Civil Law requires the adoptive father or adoptive mother to be over 40 years old. It also stipulates that the adopted child must not be older than 15 years old. ${ }^{50}$ In addition to the age condition, the Southern Civil Law stipulates that the custodian can be a man or a woman and it does not matter whether they are married or not. The Central Civil Code stipulates the adoptive age to be above 30 years of age. Besides, Article 185 of the Northern Civil Law and Article 183 of the Central Civil Law do not discriminate against sex and marital status. ${ }^{51}$ According to the Southern legislators, adoption is crucial so the adoptive child must express their opinion. Meanwhile, the adoptive child's consent condition was not recorded in the Northern Civil Law and the Central Civil Law.

$V u V$ an Mau said that the purpose of adopting in this period came from humanity, personal interests and spirituality. 'An example of adopting children as a kindness is when a well-off family adopts the young children of a destitute family. When the aim of adopting children is a personal interest means adopting a child to take them working without a salary. For example, the creditors adopt the debtor's children for adoption. Then, they will make deductions to the loan amount. Adopting for spiritual reasons means that a well-off but disasterprone family will adopt a child from a low-income family with many children, let that child take off part of the disaster and bring to the recipient's family a little happiness. ${ }^{52}$ Thus, it can be seen that the protection of children's rights was not upheld in Vietnamese law during the French invasion period.

Among the regulations on adoption, the main provisions are the rights of the child that is being adopted. Specifically, the child must be treated by the adoptive parents' family as a biological

\footnotetext{
${ }^{49}$ VU VAN, Việt Nam Dân Luật Lược Khảo 298.

${ }^{50}$ VU VAN, Việt Nam Dân Luật Lược Khảo 298.

51 VU VAN, Việt Nam Dân Luật Lược Khảo 306.

52 VU VAN, Việt Nam dân Luật Lược Khảo 294.
} 
child if the adoptive child follows the adoptive father's family name (Article 193 of the Northern Civil Code). However, in the Central Civil Code, it is not necessary to have the same surname as the adopting person for the adopted child to be treated like a biological child. This regulation is genuinely progressive as well as compatible with the current Vietnamese laws. There is also a record that the adoptive parents must nurture, take care for and educate the adoptive child, but the foster child cannot be completely identical with the biological child. ${ }^{53}$

From the case records in the Southern, $V u V$ an Mau has assessed that: The adoptive children are 'other people' they are adopted because of charity or sometimes just because the adoptive person wants to find a friend for his child to play with. Therefore, a son is only considered a kind of house-worker who does not have the right to follow-up to adoptive parents..$^{54}$

Besides, Article 201 North Civil Code and Article 200 of the Central Civil Code also stipulates that if the adoptive parent lets the adoptive child lack essential needs or cruelly treat the adopted child, the adoptive child or a relative can go to court and the adoptive parent loses his custody.

\section{Conclusion}

In summary, although it was enacted during the period when Vietnam was a divided territory and experiencing political instability, it is incorrect to suppose that Vietnamese laws of the French colonial period were enacted only to protect the interests of the French colonialists because, throughout the provisions of the three Civil Codes of this period, we still noticed that there are provisions that protected the rights of children. The children's rights stipulated during this period were also quite diverse, namely the right to survive, right to birth registration, the right to have a nationality, the right to be adopted, etc. However, it can be seen that the protection of children's rights in this period did not focus on the rights related to children's spiritual life, such as the right to study and play, the right to develop abilities, and the right to express their opinions. It is because patriarchalism is still too profound in the minds of the Vietnamese people. Besides, protecting children's rights in the period was not the legislator's primary purpose. It means the provisions in such stage were meant for protecting the interests of other subjects and led to children's protection accidentally. In conclusion, although they are not the same meaning of the rights in current Vietnamese law, these regulations have somewhat taken Vietnamese children at that stage out of some mental and physical abuse.

\section{Bibliography}

BILTON, Tony: Nhập môn Xã hội học [Introduction to Sociology]. Khoa học Xã hội 1993

DiNH THI Nga: Bảo vệ quyền trẻ em trong pháp luật Việt Nam hiện hành [Protect children's right in current Vietnamese Law]. Tạp chí khoa học DHQghn 1/2004

Gerber, Paula - GArgetT, Gargett - CAStan, Melissa: Does the right to birth registration include a right to a birth certificate. Netherlans Quarterly of Human Right 29 Neth, Issue 1/2011

53 VU VAN, Việt Nam Dân Luật Lược Khảo 307. 
HA NHU Vinh: Chế độ hôn sản pháp định trong luật Việt Nam [The legal marriage regime in Vietnamese Law]. Saion 1967

HOANG THU Trang: Ảnh hưởng của quan niệm đạo đức Nho giáo đến đời sống đạo đức ở Việt Nam hiện nay [Influence of Confucian ethics on the moral life in Vietnam today]. Khoa học xã hội Việt Nam, 7/2017

NGuYÊn DinH Tư: Chế độ thực dân Pháp trên đất Nam Kỳ [French colonial regime in Southern Vietnam]. Tổng hợp Thành phồ Hồ Chí Minh 2019

NGuYÊnN HoA Mai: Trường Nữ Sinh Thời Pháp Thuộc Ở Việt Nam: Từ góc nhìn quyền văn hóa [School for Girls Under the French Colonial Period Colonial in Vietnam: From a cultural rights perspective]. https://repository.vnu.edu.vn/bitstream/VNU_123/94896/1/KY_0541.pdf (16/01/2021)

NGUYÊNN THI Yến: Quyền trẻ em trong pháp luật Việt Nam hiện nay [Children’ rights in current Vietnamese Law]. https://phaply.net.vn/quyen-tre-em-trong-phap-luat-viet-nam-hien-nay/ (14/01/2021)

NGuYÊn Thi My Linh: The Impact of The French Colonial Law on the Development of Matrimonial Property Law in Vietnam. Díké 1/2019, 65-82.

NguYÊN THI MY Linh: The Matrimonial property Law in Vietnam 1858 - 1975 in the Mirror of the European Legal Development. BRGÖ 2/2020, 309-316.

NHU Lịch: Cứu tinh của trẻ sơ sinh không có giấy khai sinh [A newborn’s saviour without a birth certificate]. https:/ / thanhnien.vn/gioi-tre/cuu-tinh-cua-tre-khong-co-khai-sinh-1159143.html (16/01/2021)

NGuYÊN QuANG Thắng: Bước đầu tìm hiểu Luật Gia Long [The first step to learn Gia Long Code]. Văn hóa thông tin 2002

PrelozNJAK, Barbara: Modern challenges in the implementation of the child's right to know his origin. EU and Comparative Law Isues and Challenges Series 4 ECLIC 2020

THAN Bình - NGuYÊn NGOc Hà - PHAM THI Thu: Bình luận Khoa học Bộ Luật hình sự năm 2015 - Phần các tội phạm [Scientific Commentary on Criminal Code 2015 - Crimes section]. Công an nhân dân 2017

TRAn THI THANH Thanh: Nho học và giáo dục công lập ở Nam Kỳ thuộc Pháp thời kì 1867-1917 [Confucianism and public education in the French Southern period 1867-1917]. Tạp chí Khoa học Đại học Sư Phạm Thành phố Hồ Chí Minh (60) 2014

Tran VAn Luyện - Phung The Vắc - LÊ VĂN Thư - NGUYÊn MAI Bộ - PHAM THAnh Bình - NGUYEN NGOC Hà - PHAM THI Thu: Bình luận Khoa học Bộ Luật hình sự năm 2015 - Phần các tội phạm [Scientific Commentary on Criminal Code 2015 - Crimes section]. Công an nhân dân 2018

Vu VAN Mẫu: Dân Luật Lược Khảo-Quyển 1: Gia đình [Civil Law Review-Volume 1: Family]. Saigon 1962

VU VAN Mẫu: Dân Luật Khái Luận [Argumentative Civil Law]. Bộ Giáo dục và Đào tạo 1961

VU VAN Mẫu: Cổ Luật Việt Nam và Tư Pháp Sử, Quyển 1-Tập 1 [Vietnamese Law and Justice History-Volume 1]. Saigon 1973

Blackstone, William: Blackstone's Commentaries on the Laws of England (4th ed. 1876), Vol. 1

MCCLOSEKEY, Bernard: The death penalty and the right to life. Boston College Law Review, Vol. 60 January 2019 